\title{
A 60 éves Európai Szociális Karta néhány proaktív dilemmája
}

\author{
$60^{\text {th }}$ Anniversary of the European Social Charter: \\ Some Proactive Dilemmas
}

\begin{abstract}
ABSZTRAKT
Az Európai Szociális Karta az Európa Tanács emberi jogi egyezménye. 2021-ben 60 éve védi a gazdasági és szociális jogokat Európában. Az elmúlt hat évtizedben a Karta több módosításon esett át, melynek eredményeként cikkelyeinek száma bővült, és a legújabb társadalmi kihívásokra is igyekezett reflektálni. Ugyanakkor továbbra is az Európa Tanács legalapvetőbb célkitűzéseinek kíván megfelelni és érvényt szerezni: az emberi jogok, a jogállamiság és a demokrácia védelmének, amelyek megvalósulásának egyik záloga a szociális jogok tiszteletben tartása. 60 évvel a Karta és 30 évvel az ellenőrzési mechanizmus megreformálását szolgáló Torinói Jegyzőkönyv (1991) elfogadását követően az Egyezmény még mindig nem érte el teljes potenciálját. Ebben a cikkben a Karta két legismertebb ellenörzési mechanizmusának müködési dilemmái kerülnek vizsgálat alá, és néhány proaktív megoldás megfogalmazására kerül sor.
\end{abstract}

Kulcsszavak: Európai Szociális Karta, emberi jogok, szociális jogok, Szociális Jogok Európai Bizottsága, monitoring eljárás, kollektív panaszeljárás

\begin{abstract}
The European Social Charter is a human rights treaty of the Council of Europe. For 60 years, the Charter has been protecting the social and economic rights of citizens across Europe. During these years, the Charter has been revised and new rights have been included to take into account the challenges facing our modern societies. But the Charter has remained at the heart of the Council of Europe's statutory goals: human rights, rule of law and democracy, which cannot be realised without respect for social rights. However, sixty years after the adoption of the Charter, and thirty years after the adoption of the Turin Protocol of 1991 reforming the supervisory mechanism, the Convention has yet to realise its full potential. In this article the Charter's two supervisory mechanisms are analysed and some proactive dilemmas and possible solutions are outlined.
\end{abstract}

Keywords: European Social Charter, human rights, social rights, European Committee of Social Rights, monitoring procedure, collective complaint procedure

Az eredeti Európai Szociális Kartát (a továbbiakban: ESZK) 60 évvel ezelött, 1961. október 18-án fogadták el Torinóban. Az ESZK jogosítványokat és szabadságjogokat fektet le, továbbá ezeknek a részes államok általi tiszteletben tartását

* Dr. Hajdú József, egyetemi tanár, Szegedi Tudományegyetem Állam- és Jogtudományi Kar Munkajogi és Szociális Jogi Tanszék; e-mail: hajdu@juris.u-szeged.hu.

${ }^{1}$ Fontos megjegyezni, hogy a Karták (1961 és 1996) a szerződések jogáról szóló Bécsi Egyezmény értelmében elnevezésüktől függetlenül nemzetközi egyezménynek minősülnek. 
garantáló ellenőrzési mechanizmust létesít. ${ }^{2}$ Olyan, sajátos európai szociális modellt kívánt megteremteni, amely különbözik a világ többi szociális jogokat tartalmazó nemzetközi dokumentumától. ${ }^{3}$ Az eltérés legalább két kardinális jellemzőben mutatható ki. Az egyik, hogy az eredeti és a módosított Karta együtt a szociális jogok legszélesebb tárházát foglalják magukban (a módosított Karta 31 cikkelyből áll). A másik, hogy a Kartáknak duális kontrollmechanizmusa van (országjelentések és kollektív panaszeljárás). Fontosnak tartom kiemelni, hogy ezek jelentősége nem az adminisztratív előírások végrehajtásában rejlik, hanem abban, ahogy a rendelkezésre álló eszközök segítségével a szociális jogok - mint emberi jogok - minél hatékonyabb védelmét valósítsák meg.

Az ESZK napirendre vétele 2021-ben több okból aktuális. Egyrészt a szociális jogok védelme kiemelten fontos az utóbbi években kialakult, hektikus gazdasági, társadalmi és pandémiás környezetben. Másrészt az eredeti Karta 2021-ben éri meg aláírásának 60. évfordulóját, ráadásul Magyarország 2021 májusában vette át az Európa Tanács Miniszteri Bizottságának soros elnökségét. ${ }^{4} \mathrm{Az}$ elmúlt hat évtizedben az ESZK müködésével kapcsolatban számos kritika fogalmazódott meg, és ezekkel kapcsolatban több reformjavaslat is napvilágot látott. Ezek közül már több intézményesedett.

Ebben a cikkben a jobb megértés érdekében a Karták néhány általános jellemzőjét szeretném bennfentesként ${ }^{5}$ bemutatni, megvilágítva néhány belső összefüggést, és feltárva néhány problémát, amelyekre lehetséges megoldásokat is javasolni fogok.

${ }^{2}$ A Szociális Karta dióhéjban. https://www.europarl.europa.eu/meetdocs/2004_2009/documents/dv/chartesocialedepliant-/ chartesocialedepliant-hu.pdf (2021. 05. 16.).

${ }^{3}$ Grathwohl, Daphne: Little-known European Social Charter marks 50 years. DW, 2011. október 18. https:// www.dw.com/en/little-known-european-social-charter-marks-50-years/a-15466320 (2021. 05. 12.).

${ }^{4}$ Az elnökség 2021. május 21-től 2021. november 17-ig tart. A magyar elnökség a következő három súlyponti témára összpontosít: a nemzeti kisebbségek, a vallási közösségek, valamint a gyermekek és családok jogainak védelme. Ezek közül elsősorban a harmadik tartozik az ESZK hatáskörébe.

5 Talán használhatom ezt a szót, mert ebben az évben lesz kilenc éve, hogy a Karták ellenőrzését végző Szociális Jogok Európai Bizottságának tagjaként szolgálom a szociális jogok minél hatékonyabb érvényesülését. 


\section{A szociális jogok mint emberi jogok megítélése az Európai Szociális Karta tükrében}

Európában a szakértők többségének álláspontja szerint a második generációs ${ }^{6}$ emberi jogok ${ }^{7}$ közé sorolt gazdasági, szociális és kulturális jogok multilaterális és regionális szintủ védelmének az egyik legfontosabb letéteményese az Európa Tanács Európai Szociális Kartája (1961) és Módosított Kartája (1996). Az első Kartát alapvetően az ENSZ Közgyülése által 1948-ban elfogadott Emberi Jogok Egyetemes Nyilatkozata inspirálta, amelynek 22-26. cikkei - tágabb értelemben vett - szociális jogokat is deklaráltak. Ezen túlmenően legkorábbi előzményének az ILO 1944-ben megjelent Philadelphiai Nyilatkozata, valamint a szociális biztonságot érintő cikkely (12. cikk) esetében az ILO 102. sz. Egyezménye (1952)8 tekinthető. A módosított

${ }^{6}$ Az emberi jogokról szóló szakirodalomban főáramlatként jelen van az emberi jogok generációk szerinti csoportosítása. Első generációs jogok a politikai és szabadságjogok, második generációs jogok a gazdasági, szociális és kulturális jogok, és különböző további csoportosítások említenek még harmadik, sőt negyedik generációs emberi jogokat is. A generációk számozás szerinti csoportosítása óhatatlanul sorrendet (megkockáztatom, fontossági rangsort) is létrehoz. Elég az Emberi Jogok Európai Egyezményének (EJEE) és az ESZK védelmi mechanizmusának intézményesülésére gondolni. A tradicionális felfogásban első generációs emberi jogokat tartalmazó 1950-es EJEE-ben deklarált emberi jogok védelmére létrehozták az Emberi Jogok Európai Bíróságát, míg a közvéleményben általában „másodlagosnak” tekintett második generációs emberi (szociális) jogok védelmére „csak” egy ellenőrzést végző Bizottság (a Szociális Jogok Európai Bizottsága) jött létre. A két intézmény hatásköre és a részes államokra gyakorolt jogi hatása nagyon különböző, a második generációs emberi (szociális) jogok védelmének hátrányára.

A magam részéről alapvetően nem értek egyet az emberi jogok generációk szerinti felosztásával. Ennek egyik alapja az 1993-as Bécsi Nyilatkozat és cselekvési program (VDPA), amely az Emberi Jogok Világkonferenciáján 1993. június 25-én Bécsben elfogadott nyilatkozat az emberi jogok minősítésére vonatkozóan. A VDPA I. rész (5) bekezdése értelmében: „Az emberi jogok oszthatatlan, egymástól függő és egymással összefüggő jogok." A VDPA hangsúlyozza, hogy minden emberi jog egyenlő fontosságú, és igyekszik megszüntetni a minőségi megosztottságot polgári és politikai jogok és gazdasági, szociális és kulturális jogok között. Ennek értelmében a nemzetközi közösségnek az emberi jogokat globálisan, igazságos és egyenlő módon, azonos alapon és ugyanazon hangsúlyozással kell kezelnie. A nemzeti és regionális sajátosságokat, valamint a különféle történelmi, kulturális és vallási hátteret figyelembe kell venni, az államok kötelessége politikai, gazdasági és kulturális rendszerüktől függetlenül előmozdítani és védeni az összes emberi jogot és alapvető szabadságot. Ha ezt a tételt igaznak tekintjük, akkor okafogyottá válik az emberi jogok generációk szerinti mesterséges megkülönböztetése. A másik gyakori érv, hogy az első generációs emberi jogok esetén az államnak tűrési kötelezettsége áll fenn, ami alapvetően nem kerül pénzbe. Ezzel szemben a második generációs emberi (szociális) jogok esetén az államnak cselekvési kötelezettsége van az egyén felé. Ez általában valóban így van, de a szociális jogok érvényesülését nem lehet kizárólag anyagi források meglétéhez kötni. Másképpen fogalmazva, az emberi jogok jellegüket tekintve nem függhetnek a pénzügyi forrásoktól. (Lásd a Bizottság esetjogát a 2008-as gazdasági válságot követően.) Természetesen a napi gyakorlatban ez másként jelenhet meg (például ha nincs forrás a táppénzre, akkor a keresőképtelen munkavállalók nem kapnak táppénzt). Ezen pragmatikus megközelítéstől elvonatkoztatva az emberi jogokra oszthatatlanul minden embernek alanyi joga van, és ezek csak abban különbözhetnek, hogy egy adott konkrét személy esetén (még egy államon belül is) az igényérvényesítés melyik fázisába jutnak el. Továbbá az is vitathatatlan, hogy minden emberi jog érvényesüléséhez - függetlenül annak „generációs” hovatartozásától szükség van az állam jelenlétére. Ebben sincs elvi különbség a generációk között, csak esetleg a mértékében lehetnek eltérések.

${ }^{7}$ BRILLAT, Regis: Division of social human rights into fundamental rights and welfare/development rights. In: Johanson, Niko-Mikkola, Matti (eds.): Reform of the European Social Charter. Ministry for Foreign Affairs of Finland, 2011, 45-49.

${ }^{8}$ A szociális jogok minimum standardjairól. 
Kartára jelentős hatással volt továbbá az ENSZ Gazdasági, Szociális és Kulturális Jogok Nemzetközi Egyezségokmánya, amelyet az ENSZ Közgyülése 1966-ban fogadott el. A 1961-es Karta alapvetően a két ENSZ univerzális emberi jogi norma közé ékelődött be, és korát jóval megelőzve a szociális jogok viszonylag széles katalógusát ${ }^{9}$ foglalta össze egy dokumentumban. ${ }^{10}$ Mint a bevezetöben említettük, az eredeti torinói Karta 2021-ben ünnepli létrejöttének 60. évfordulóját, amely hat évtizede - a legtágabb földrajzi értelemben vett - Európa emberi (szociális) jogi iránytüje. Az eredeti Kartát módosító 1996-os Kartával együtt minden ember - legyen az gyermek, fiatal, aktív vagy időskorú - hétköznapjaira kihatással van.

A 47 európai országot ${ }^{11}$ - köztük az Európai Unió tagállamait is - összefogó Európa Tanács (a továbbiakban: ET) saját meghatározása szerint „a földrész vezető emberi jogi szervezete". Az emberi jogok, a demokrácia és a jogállam védelmét szolgáló multilaterális együttmüködés. 1949. május 5-én aláírt alapszabályának 3. cikke a tagállamok kötelezettségévé teszi az emberi jogok és alapvető szabadságok tiszteletben tartását. E kötelezettség teljesítésének szükségességét az 1950 novemberében Rómában aláírt Emberi Jogok Európai Egyezményében (a továbbiakban: EJEE), majd a hozzáfüzött kiegészítő jegyzőkönyvekben - a védelemben részesítendő emberi jogok felsorolásával - is megfogalmazták. ${ }^{12}$ Az EJEE expressis verbis nem rendelkezik a szociális jogokról, hanem e jogokat - annak reményében, hogy a gazdasági fellendülés időszakában a szociális jogok biztosításának anyagi lehetőségei automatikusan megteremtődnek - egy külön nemzetközi egyezmény, az 1961-ben aláírt Európai Szociális Karta fogalmazta meg.

Az ESZK célja az alapvető emberi (szociális) jogok biztosítása az ET tagállamainak állampolgárai részére. A szociális jogok fundamentuma - ahogyan az ESZK-t gyakran nevezik Európában - 1961 óta jelentősen bővült. Ma már az ET eredeti egyezménye, az ESZK mellett további négy nemzetközi egyezmény kapcsolódik hozzá. Az öt egyezmény így együttesen, de külön-külön is az európai értékrend szerves és releváns részét alkotja.

Elsőként a Kiegészítő jegyzőkönyv született meg (Strasbourg, 1988. május 5.), amely az ESZK rendelkezéseinek bővítését és bizonyos modernizálását szolgálta négy új jog beépítése útján, hozzávetőleg negyed évszázaddal az ESZK keletkezését

\footnotetext{
${ }^{9}$ Az 1961-ben elfogadott Európai Szociális Karta 19 cikkben sorolta fel a gazdasági és szociális jogokat. A Revideált Kartában (1996) ez a katalógus 31 cikkre bővült. A két Karta közötti átfedés és pozitív tartalmi különbözőség jól érzékelhető.

${ }^{10}$ A jogtudomány nem egységes a szociális jogok megitélése tekintetében. A szociális jogok emberi jogi mivoltát megkérdőjelező nézetek általában arra helyezik a hangsúlyt, hogy ezek a jogok nem következnek közvetlenül az ember emberi mivoltából, és nem minősülnek alanyi jognak sem, mert nem kikényszeríthetőek. Mások az első generációs szabadságjogok sérelmének lehetőségét látják a szociális jogok érvényesülése érdekében szükséges aktív állami közremüködéssel összefüggésben, és vannak, akik az állam aktuális gazdasági teherbíró képességének oldaláról közelítik meg a kérdést. Vesd össze: HALMAI Gábor-TótH Gábor Attila: Az emberi jogok rendszere. In: Halmai Gábor-Tóth Gábor Attila (szerk.): Emberi jogok. Osiris, Budapest, 2011, 86.

${ }^{11}$ Az ESZK-t és a Módosított Kartát az ET 47 részes államából mindössze négy - Liechtenstein, Svájc, Monaco és San Marino - nem írta alá.

$32{ }^{12}$ Az EJEE és az ahhoz tartozó nyolc kiegészítő jegyzőkönyv Magyarországon az 1993. évi XXXI. törvénnyel került kihirdetésre.
} 
követően. Ezek a nemen alapuló hátrányos megkülönböztetés nélküli esélyegyenlőséghez és egyenlő bánásmódhoz való jog a munkavállalást és a hivatást illetően; a munkavállalók joga a tájékoztatáshoz és a véleménynyilvánításhoz; a munkavállalók joga a munkafeltételek és a munkakörnyezet meghatározásában és javításában való részvételhez; illetve az idősek joga a szociális védelemhez. A második kiegészítés az ESZK ellenőrző mechanizmusa hatékonyabbá tétele érdekében kiadott Módosító jegyzőkönyv az Európai Szociális Kartához (Torino, 1991. október 21.), ${ }^{13}$ a harmadik a Kollektív Panaszok Rendszerének Biztosításáról szóló Kiegészítő jegyzőkönyv (1995. november 9.), amely a Karta ellenőrzési mechanizmusának hatékonyabbá tétele érdekében született. A negyedik bővítést a szociális és gazdasági jogokat egyedülálló részletességgel tartalmazó Módosított Európai Szociális Karta (Strasbourg, 1996. május 3.) hozta. ${ }^{14}$

Magyarország az eredeti Kartát, valamint az időközben további négy dokumentummal kibővült „kartacsomagból”15 az 1988-as kiegészítő jegyzőkönyvet és az 1991-es módosító jegyzőkönyvet 1999-ben hirdette ki, mely által az említett dokumentumok a hazai jog részévé váltak. ${ }^{16}$

Az ESZK preambuluma ünnepélyesen kinyilvánítja, hogy az Európa Tanács a tagállamain keresztül az Európai Szociális Kartában, valamint annak jegyzőkönyveiben biztosítja lakosságuk számára a szociális jogokat annak érdekében, hogy javítsák életszínvonalukat és szociális jólétüket. Ennek szellemében az 1990. november 5-én Rómában az emberi jogokról tartott miniszteri konferencia egyfelöl hangsúlyozta valamennyi emberi jog oszthatatlan természetének megörzését (legyenek azok állampolgári, politikai, gazdasági, szociális vagy kulturális jogok), másfelöl pedig azt, hogy új lendületet kell adni az ESZK ügyének. Ezért az 1991. október 21-22-én Torinóban tartott miniszteri konferencián elhatározták, hogy korszerüsítik az ESZK-t és úgy módosítják, hogy figyelembe veszik azokat az alapvető szociális változásokat, amelyek a szöveg elfogadása óta eltelt 30 évben következtek be. A tervek szerint a Módosított Kartának fokozatosan át kell vennie az eredeti ESZK helyét.

${ }^{13}$ A Magyar Köztársaság 1991-ben írta alá, megerősítéséröl pedig az Országgyűlés a 124/2003. (XI. 21.) OGY határozattal döntött.

${ }^{14}$ Magyarország 2009. április 20-án ratifikálta a következő cikkelyeket és bekezdéseket (2009. évi VI. törvény a Módosított Európai Szociális Karta kihirdetéséről): 1. Cikk A munkához való jog; 2. Cikk Az igazságos munkafeltételekhez való jog; 3 . Cikk $A$ biztonságos és egészséges munkafeltételekhez való jog; 5 . Cikk Szervezkedési jog; 6. Cikk A kollektív alkuhoz való jog; 7. Cikk (1) A gyermekek és fiatalok védelemhez való joga; 8. Cikk A dolgozó nők védelemhez való joga anyaság esetén; 9 . Cikk A pályaválasztási tanácsadáshoz való jog; 10. Cikk A szakképzéshez való jog; 11. Cikk Az egészség védelméhez való jog; 12. Cikk (1) A társadalombiztosításhoz való jog; 13. Cikk A szociális és egészségügyi segítségre való jog; 14 . Cikk A szociális jóléti szolgáltatásokból való részesülés joga; 15. Cikk $A$ fogyatékossággal élő személyek joga a függetlenséghez, a társadalmi beilleszkedéshez és a közösség életében való részvételhez; 16. Cikk A család joga a szociális, jogi és gazdasági védelemhez; 17. Cikk A gyermekek és fiatalok szociális, jogi és gazdasági védelemhez való joga; 20. cikk A nemen alapuló megkülönböztetés nélküli esélyegyenlöségre és egyenlő elbánásra való jog a munkavállalást és a hivatást illetően; 21. cikk Az információhoz és konzultációhoz való jog és 22. cikk A munkafeltételek és a vállalkozáson belül a munka környezetének megszabásában és javitásában való részvétel joga.

15 KöNCZEI György: Mi is az Európai Szociális Karta? Fundamentum, 1998/3, 135-142.

${ }^{16}$ KozMÁNÉ SZIGETI Andrea: A szociális jogok európai egyezménye és magyarországi végrehajtása. Jog, állam, politika, 2009/4, 91-160. 
Ez a mai napig nem történt meg maradéktalanul, ezért az egyes államok jelentéseinek vizsgálatakor külön kell értékelni a régi és az új Karta részes államait.

Az ESZK lényeges jellemzője, hogy aláírásakor, illetve megerősítésekor a részes államoknak lehetőségük van arra, hogy a benne szereplő 31 gazdasági és szociális jog közül ne az összeset, hanem - „à la carte-módon” - csak egy részüket fogadják el magukra nézve kötelezőnek. ${ }^{17}$ Ezt nevezik részleges ratifikációnak. ${ }^{18} \mathrm{~A}$ teljes „à la carte" szabadságot némileg korlátozza, hogy az ESZK meghatározza a kötelezően elfogadandó cikkek minimális számát. Ezek a cikkek kiemelkedő jelentőséggel bírnak, mert ezek adják az úgynevezett „kemény magot”: az ide tartozó hét cikkből'19 legalább öt elfogadása kötelező.

\section{Az Európai Szociális Karta ellenőrző mechanizmusa}

\subsection{A Szociális Jogok Európai Bizottsága}

Az ESZK garanciális, átlátható müködésének nélkülözhetetlen feltétele a szakmai ellenőrző szervként müködő Szociális Jogok Európai Bizottsága ${ }^{20}$ (a továbbiakban: Bizottság). Legátfogóbb feladata annak folyamatos vizsgálata, hogy a részes álla-

${ }^{17} \mathrm{Az}$ à la carte rendszer véleményem szerint egy paradox jogintézmény. Látszólagos előnye, hogy az ESZK összes cikkelye helyett elég a „kemény magot” ratifikálni, és ezzel a minimummal az adott állam az ESZK-n „belülre” kerül. A valóságban azonban ez a lehetöség azzal a következménnyel járhat, hogy elég ratifikálni az ESZK cikkelyeinek körülbelül a negyedét is, vagyis nagyon sok védendő szociális jog „obligon kívül” marad. Ezen kívül egyenlötlen helyzetbe kerülhetnek az államok mind morálisan (abban, hogy milyen széles a szociális jogok védelmi ernyője), mind pénzügyileg (abban, hogy hány cikkely megvalósítását kell finanszírozni). Amelyik állam több cikkelyt ratifikál és be is tartja azokat, magasabb védettségi szintet nyújt, mint azok az államok, amelyek a minimumhoz közeli, de még elégséges cikkelyt ratifikálnak. Ez az eltérés az áruk és szolgáltatások nemzetközi piacán akár versenyhátrányt is okozhat a szociális jogokat nagyobb számban ratifikáló államok számára. Az à la carte ratifikáció kiegyensúlyozatlanságának kiküszöbölését segítő megoldás, hogy a Bizottság a részes államokat arra igyekszik rábírni, hogy minél dinamikusabban és minél több cikkelyt ratifikáljanak. (Ez csak önkéntes alapon lehetséges, lásd alább az el nem fogadott ESZK cikkelyekre vonatkozó eljárást.) A kiegyensúlyozottabb ratifikálás egy másik fontos megoldása lehetne, ha a Miniszterek Bizottsága nyomatékosabban hangsúlyozná és támogatná az államokat, hogy az eredeti ESZK helyett a módosított Kartát fogadják el, és a még hiányzó cikkelyekből is minél többet ratifikáljanak. További megoldási javaslatok is felvetődnek, ezek azonban csak az ESZK módositása után válnak lehetségessé. Egyrészt ki lehetne bővíteni a „kemény magot”, így az ESZK védettségi köre és az államok közötti kiegyensúlyozottság rögtön javulna. Másrészt, bár több bizonytalanságot hordoz magában, de követendő példa lehet az ILO korábbi gyakorlata, amely - versenykiegyenlítő szerepe miatt - lehetővé tette a feltételes ratifikáció jogintézményét. Ennek értelmében minden állam „összevárta”, hogy a „kemény magon” kívüli adott cikkely ratifikálására a többi részes állam is kész legyen. Amikor mindenki készen áltt, akkor, de csak akkor írták alá, kiegyenlítve ezzel a szociális jogi eredetủ piaci versenyfeltételeket.

${ }^{18}$ A részleges ratifikációval kapcsolatban érdemes utalni az „optimális minimum” föszabályára, amely alapján csak azon rendelkezéseket célszerủ elfogadni, amelyeknek a magyar jogrendszer és -gyakorlat már megfelel, illetőleg amelyek esetében a megfelelés esetleg kismértékủ módosítással, illetve a legkisebb költségvetési kiadással biztositható.

19 1., 5., 6., 12., 13., 16. és 19. cikkek.

${ }^{20}$ Korábbi elnevezéssel Független Szakértők Bizottsága. Lásd JAKAB Nóra: Az Európai Unió szociálpolitikájának alapjai az elsődleges és másodlagos jogforrásokban, avagy az Európai Unió szociálpolitikájának a fejlődése. Publicationes Universitatis Miskolcinensis, Sectio Juridica et Politica, 2007/1, 337-354. 
mok betartják-e az ESZK-ban rögzített vállalásaikat. A Bizottság tizenöt független tagját az ET Miniszteri Bizottsága választja hatéves időtartamra, amely egyszer további hat évre megújítható. ${ }^{21} \mathrm{~A}$ Bizottság arról dönt, hogy a részes államok jogi normái és joggyakorlata megfelel-e a Kartákban foglalt cikkelyeknek. ${ }^{22}$

Az ellenőrzési mechanizmusnak két formája van: a nemzeti jelentéstételen alapuló vizsgálati (monitoring) eljárás és az 1998-ban bevezetett petíciós jellegü kollektív panaszeljárás. ${ }^{23} \mathrm{~A}$ kettő között alapvető különbség, hogy a jelentéstételen alapuló rendszer minden részes állam esetén kötelező, ellenben a kollektív panaszeljárás csak azokra az államokra terjed ki, akik ratifikálták a vonatkozó Kiegészítő Jegyzőkönyvet. A gyakorlatban mindkét mechanizmus müködik, de az ESZK-nak való megfeleltetés elsődleges eszköze szükségszerủen a nemzeti jelentésen alapuló bizottsági vizsgálat, hiszen a jelentéstételi kötelezettség a Bizottság felé minden államra vonatkozik, míg a kollektív panaszeljárásra vonatkozó protokollt csak 17 állam ratifikálta napjainkig. ${ }^{24}$

E két ellenőrzési mechanizmust egészíti ki az a speciális eljárás, amellyel a Bizottság egy előzetes eljárás keretében, a Bizottság és az érintett részes állam képviselöinek részvételével lefolytatott közös értékelést követően arra igyekszik ösztönözni az érintett államot, hogy ratifikálja az ESZK még el nem fogadott cikkelyeit, illetve a kollektív panaszeljárásra vonatkozó Kiegészítő Jegyzőkönyvet. Ezt nevezik „Az el nem fogadott cikkelyekre vonatkozó eljárásnak” (procedure on non-accepted provisions of the Charter). A következökben erröl a három eljárásról adunk rövid áttekintést.

\footnotetext{
${ }^{21}$ A Bizottság tagjainak jelölése speciális eljárásban történik. Elöször az ESZK részes államait öt csoportba sorolják. (A csoportok besorolása 2019-ben némileg megváltozott annak érdekében, hogy a tagok túlnyomó részben ne csak EU- és EGT-tagállamokból kerüljenek ki. Létrehoztak egy olyan országcsoportot, amelyben EU- és EGT-tagállamok egyáltalán nem szerepelnek. Ennek tagjai Albánia, Azerbajdzsán, Bosznia és Hercegovina, Moldova, Montenegró, Oroszország, Szerbia, Észak-Macedónia, Törökország és Ukrajna. Az első négy csoportba Grúzia kivételével továbbra is csak EU- és EGT-tagállamok kerültek.) Minden évben annyi új tagot lehet jelölni az adott csoportból, ahány személynek lejár a mandátuma. Minden részes állam javasolhat jelöltet, egy ország csak egyet, de magában a Bizottságban sem lehet egy országból több tag. Férfi és női jelöltek egyaránt javasolhatók, és a Miniszteri Bizottság figyelmet fordít a nemek kiegyensúlyozott arányára. (Lásd Rec. (81)6 30/04/1981 on the Participation of women and men in an equitable proportion in committees and other bodies set up in the Council of Europe.) A jelölt nevét az ET fötitkárához kell eljuttatni, aki továbbítja a jelöléseket a Miniszteri Bizottsághoz, amely titkos szavazással és egyszerủ többséggel dönt. Amennyiben az első szavazás után még marad be nem töltött pozíció, akkor következik a második forduló. Itt a legtöbb szavazatot kapott jelölt nyeri el a helyet. A Bizottság tagjai túlnyomó részben jogi végzettségủek, alapvetően alkotmányjogászok, nemzetközi jogászok, emberi jogi szakértők és munka-, illetve szociális jogászok. Vannak köztük (többségben) tudományos háttérrel rendelkezők és nyugalmazott kormánytisztviselők, valamint kisebb számban bírák, illetve emberi jogi szervezeteknél dolgozó szakértők.

22 Lásd az ESZK 1991-es Torinói Jegyzőkönyvvel módosított 24. cikkét. A tagok emberi (szociális) jogi megközelítését és gondolkodásmódját meghatározó kettős - alkotmányjogi és szociális jogi alapon nyugvó - dogmatikai indíttatás jól látható.

23 JAKAB: i. m., 342.

${ }^{24}$ Véleményem szerint ennek az az oka, hogy a kollektív panaszeljárás egy nagyon alapos és mélyreható jogi helyzetértékelés, ami sok esetben meg nem felelést (non-conformity) eredményez, és ezek az államok nem kívánják kitenni magukat a negatív döntés jogi és politikai következményeinek.
} 


\subsection{A nemzeti jelentésen alapuló vizsgálati (monitoring) eljárás}

A részes államok évenként tematizált jelentést ${ }^{25}$ nyújtanak be arról, hogyan hajtják végre az általuk ratifikált ESZK cikkelyeket a jogrendszerükben és a joggyakorlatukban. A Bizottság az ESZK-t élő és organikus normaként tekinti, ezért nemcsak a jogszabályokban lefektetett jogi előírásokat, hanem azok gyakorlati végrehajtását is vizsgálja. ${ }^{26} \mathrm{~A}$ Bizottság megvizsgálja az államok jelentéseit, és dönt arról, hogy az adott országban a jogi feltételrendszer megfelel-e az ESZK-ban foglalt előírásoknak. A Bizottság három módon minősíti a nemzeti jelentéseket: megfelelő (conformity), nem megfelelő (non-conformity) vagy elhalasztja a döntést (deferral). ${ }^{27}$

${ }^{25}$ Egy 2007-ben bevezetett reform alapján az ESZK cikkelyeit négy részre osztják, és minden államnak évente kell jelentést benyújtania az adott évre eső cikkelyekről. Ez összességében azt jelenti, hogy a négyéves ciklus alatt minden cikkely sorra kerül. 2014-ben egy újabb reform eredményeként a kollektív panaszeljárásra vonatkozó Kiegészítő Jegyzőkönyvet aláíró államoknak ún. egyszerűsített jelentést (simplified report) kell benyújtaniuk. Paradox módon ez komplikálttá és nehézkessé tette az eljárást, mert az érintett államok egy része olyan rövid jelentést küldött, hogy abból nehéz volt megítélni a valós helyzetet. A módosítás mögött az a megfontolás húzódott meg, hogy kollektív panaszt bármely ratifikált cikkely megsértése esetén bármikor elő lehet terjeszteni a Bizottsághoz. A valóságban ez nem ennyire egyszerü mechanizmus, mert csak egy előre meghatározott listán szereplő szervezetek - elsősorban nemzetközi NGO-k és reprezentatív munkaadói szervezetek és szakszervezetek, tehát magánszemélyek nem - tudnak kollektív panaszt előterjeszteni. További eltérés, hogy a nemzeti jelentéseket minden esetben biztosan vizsgálja a Bizottság, ezzel szemben a kollektív panaszok előzetes vizsgálaton esnek keresztül. A Bizottság érdemben csak akkor foglalkozik a kérdéssel, ha a panasz zöld utat kapott az előzetes vizsgálat után (decision on admissibility). A másik probléma, hogy egy kollektív panasz nem szükségképpen fedi le az adott vizsgálati ciklusban vizsgált öszszes cikkelyt. A következő probléma, hogy a kollektív panaszeljárás időtartama az éves vizsgálati cikluson rendszerint túlnyúlik. Átlagban a kollektív panaszeljárás 2-3 év alatt zárul le. Összességében megállapítható, hogy az egyszerűsített eljárás sok esetben nem nyújt átfogó képet az adott ciklusban vizsgált összes cikkelyről. Álláspontom szerint, bár az egyszerűsített eljárás hátterében a kollektív panaszeljárás minél több állam általi elfogadásának ösztönzése állt, a fentiekre tekintettel nem tölti be rendeltetését.

${ }^{26}$ A joggyakorlati valóság minél jobb feltárása érdekében - egy adott cikkely vizsgálatakor - a Bizottság az alábbi lehetőségekkel él: az ESZK 27. cikkely (2) bekezdése értelmében az érintett nemzetközi munkáltatói és munkavállalói érdekképviseletek képviselőit meghívhatja a Bizottság ülésére (erre nagyon ritkán kerül sor); az érintett részes államban müködő érdekképviseleti szervek meghívása, de csak olyan keretek között, amivel az érintett állam egyetért (tudomásom szerint még nem került rá sor); a nemzeti szinten működő munkáltatói és munkavállalói érdekképviseletek és NGO-k a részes állam által beterjesztett nemzeti jelentéshez megjegyzéseket és további kiegészítő információkat nyújthatnak be, amely határideje a tárgyév áprilisának utolsó napja (ESZK 23. cikk); a Bizottság felkutat minden rendelkezésre álló nemzetközi jelentést (például az EUROSTAT, az OECD, az ILO, az EU, a WB, INGO-k dokumentumait). Ez utóbbit nagyon sűrűn alkalmazzák, mert sok esetben a nemzeti jelentések meglehetősen hiányosak. Ugyanakkor nehezíti az egyenlő alapon történő vizsgálat lehetőségét, hogy például az EU-s tagállamok esetén sokkal több információs forrás áll rendelkezésre, mint egyes kevésbé vizsgált EU-n kívüli országok esetén. Lásd a Bizottság eljárási szabályzatának 21. és 21/A. pontjait. https://rm.coe.int/rules-rev-320-en/1680a2c899 (2021. 05. 12.).

${ }^{27}$ Az első két minősítés magától értetődőnek tűnik, egy megjegyzést mégis szeretnék hozzáfűzni. A Bizottság az értékeléskor találhat olyan - nem kardinális - értékelési szempontokat, amelyekre az érintett állam nem nyújtott be egyáltalán információt, vagy amit benyújt, az nem elégséges. Ilyen esetben az értékelésben kérdés(eke)t fogalmaz meg, amely(ek)re a részes államnak a következő jelentésében válaszolnia kell. Ilyenkor a minősítés feltételes megfelelés. Ennek az a következménye, hogy amennyiben az állam a következő jelentési ciklusban sem válaszol a feltett kérdésre, akkor figyelmeztetést (warning) kap, és ha erre sem válaszol, akkor az azt követő ciklusban „nem megfelelt” minősítést kap. A döntés elhalasztására alapvetően két esetben kerül sor. Egyrészt szokásjogi alapon az első jelentését benyújtó állam vagy megfelelt, vagy deferral minősítést kap (a Bizottság az első jelentésre tekintettel „elnézőbb”). Másrészt akkor, ha nem áll rendelkezésre elegendő információ, amely alapján egyértelműen eldönthető, hogy az állam megfelel vagy sem (ilyenkor természetesen számos kérdés kerül megfogalmazásra a következő jelentési ciklusra). 
Az országjelentésekkel kapcsolatban számos probléma merülhet fel. Gyakran elöfordul, hogy nem érkeznek meg határidőre, illetve vagy nagyon terjengősek, mégis sok kérdést megválaszolatlanul hagynak, vagy éppen ellenkezőleg, nagyon szükszavúak (elsősorban olyan államok esetén, ahol több cikluson keresztül „megfelelö” volt az értékelés eredménye). Szintén nehézséget jelent, hogy a ciklusok évekkel korábbi állapotról szólnak, tehát soha nem az aktuális jogi háttér kerül megvizsgálásra.

A fenti problémák kezelésére több megoldás körvonalazódott. Az egyik az egyszerűsített - pontosabb fordításban fókuszált - jelentési eljárás (targeted questions). Ennek keretében a Bizottság összeállít egy célirányos kérdéssort, ami az adott állam által ratifikált cikkelyek leginkább problematikus pontjaira kérdez rá. Egy másik elképzelés az lehet, hogy minden állam egy speciálisan erre a célra készített jelentési naptár szerint, a négyéves ciklus végén készít jelentést az általa ratifikált cikkelyekről garanciális céllal. További megoldás lehet, ha a négyéves ciklus közepén - a két tematikus jelentés között - egy időközi, külön erre a célra összeállított kérdöíven alapuló speciális jelentést kell készíteni, amely minden lényeges kérdésröl érdemben szolgáltat információt. A magam részéről az első javaslattal értek egyet. Ennek az az indoka, hogy a Bizottság az országjelentések értékelésénél a Digest néven ismert ESZK Kommentár és esetjog ${ }^{28}$ irányadó pontjait tekinti kiindulási alapnak. A célzott kérdések alapvetően ezekre a kulcspontokra, illetve néhány aktuális kérdésre (például migráció vagy COVID-19 pandémia ${ }^{29}$ ) fókuszálnak.

A jelentések vizsgálatáról a Bizottság évente publikálja döntéseit, amelyek elnevezése "következtetések” (conclusions). A részes államok alapvető kötelessége, hogy a talált hiányosságokat kijavítsák. Amennyiben valamely állam olyan mértékben hagyja figyelmen kívül a Bizottság döntését, hogy az az ESZK megsértésének minősül, a Miniszteri Bizottság figyelmeztető határozatot (resolution) vagy ajánlást (recommendation) intéz az adott államhoz, a hatályos jog és/vagy a gyakorlat megváltoztatására irányuló kéréssel. A Miniszteri Bizottság munkáját a részes államok kormányainak képviselőiből álló Kormányzati Bizottság (Governmental Committee) készíti elő, az európai munkáltatói szervezetek és szakszervezetek megfigyelőinek közreműködésével.

A reformelképzelések kapcsán az is megfogalmazódott, hogy létre kellene hozni a részes államok munka- és szociális ügyekért felelős minisztereiből egy bizottságot Szociális Kohéziós Operatív Bizottság (Steering Committee on Social Cohesion) néven, amely minden második évben felülvizsgálná a legaktuálisabb kérdéseket, trendeket (például a COVID-19 pandémia munkaerőpiacra és szociális ellátórendszerre gyakorolt hatását). A magam részéröl ezt az elképzelést támogatom, azzal a feltétellel, hogy a Kormányzati Bizottság és a Szociális Jogok Európai Bizottsága együttesen készítse elő a megvitatandó kérdéseket. A Bizottság egyébként is rendszeresen készít az ESZK-val kapcsolatos értelmező állásfoglalásokat (statement of interpretation). ${ }^{30}$

\footnotetext{
${ }^{28}$ Digest of the Case Law of the European Committee of Social Rights. https://rm.coe.int/digest-2018-parts-i-iiiii-iv-en/1680939f80 (2021. 05. 22.).

${ }^{29}$ Social Rights in times of pandemic. https:/www.coe.int/en/web/european-social-charter/social-rights-in-timesof-pandemic (2021. 05. 30.).

${ }^{30}$ A legutóbbit például 2021 májusában fogadták el, amely a COVID-19 pandémiának az ESZK cikkelyeire gyakorolt hatásáról szólt, és egyidejüleg iránymutatásul szolgál a tagállamoknak, hogy a következő ciklusban milyen speciális kérdésekről kell majd jelentést tenniük.
} 


\subsection{Kollektív panaszeljárás}

Az aláírásra 1995-ben megnyílt és 1998-ban hatályba lépett Kiegészítő Jegyzőkönyv alapján a Bizottsághoz az ESZK megsértésére vonatkozó panasz nyújtható be. Ez a jogintézmény szintén ambivalens vonásokat mutat. Azon részes államokban, amelyek elfogadták a Kiegészítő Jegyzőkönyvet, egy újabb, a jelentéstételi mechanizmuson kívüli fontos kontradiktórius ${ }^{31}$ eszközzel bővült a szociális jogok védelmét szolgáló eszközrendszer, ezzel is növelve a szociális jogok védelmének hatékonyságát. Ugyanakkor, mivel a ratifikáló államok száma még mindig relatíve alacsony, ${ }^{32}$ tovább mélyítette az emberi (szociális) jogok védelmére vonatkozó mechanizmusok eltérését az egyes részes államok között. Vannak ugyanis olyan részes államok (és ez a többség), akikre „csak” a jelentéstételi kötelezettségi eljárás vonatkozik, és vannak olyanok, akikre ezen túlmenően a kollektív panaszeljárás is irányadó, egy kvázi bírósági jellegú eljárás, amit két éven belül a felülvizsgálati (follow up) eljárás ${ }^{33}$ követ. A kollektív panaszeljárást is vállaló állam esetén ez fokozott - nemzetközi és hazai szervek által kezdeményezett - ellenőrzést, ugyanakkor polgárai számára magasabb szociális védelmi garanciát jelent.

Valamennyi olyan ország esetében, amely ratifikálta a kollektív panaszeljárásról szóló Kiegészítő Jegyzőkönyvet, az alábbi szervezetek jogosultak panaszt benyújtani a Bizottsághoz: az Európai Szakszervezeti Szövetség (ETUC), az Európai Munkaadók és Gyáriparosok Szövetsége (UNICE) és a Munkaadók Nemzetközi Szervezete (IOE); azok a nem-kormányzati szervezetek (NGO-k), amelyeknek „résztvevő” státuszuk van az ET mellett, illetve ilyenként szerepelnek az erre a célra a Kormányzati Bizottság által felállított listán; valamint az adott ország reprezentatív munkaadói érdekképviseleti szervezetei és szakszervezetei. Ezen felül azon országok tekintetében, amelyek külön nyilatkozatban ehhez is hozzájárultak, az adott államban müködő nem-kormányzati szervezetek is megindíthatják az eljárást. A magam részéről ezzel a jogosulti körrel alapvetően egyetértek, de bővíteném két hasonló jellegủ szervezettel: egyrészt az európai ombudsmannal, másrészt a részes államokban müködő ombudsmanokkal vagy ezzel egy tekintet alá eső személyekkel vagy testületekkel (például Magyarországon az alapvető jogok biztosával).

A kollektív panaszbeadványnak a következőket kell tartalmaznia: a panaszt benyújtó szervezet nevét és elérhetőségét; annak bizonyítékát, hogy a panaszt be-

${ }^{31}$ Az eljárás a panaszt benyújtó szerv kérelmének előterjesztésével indul, és a befogadást követően az érintett államnak joga van ellenkérelmet előterjeszteni.

${ }^{32} 2021$ májusáig 17 állam. A legutolsó aláíró Spanyolország volt (2021. május 17.).

${ }^{33}$ A felülvizsgálati eljárást a Kollektív Panaszeljárásról rendelkező Kiegészítő Jegyzőkönyv 9. cikkelyének (1) bekezdése írja elő. Ennek alapján, ha a kollektív panaszeljárás végén a Bizottság marasztalja az érintett államot (non-conformity), akkor a Miniszteri Bizottság köteles ellenőrizni, hogy a döntésben foglaltakat az állam végrehajtja-e. Az érintett állam köteles akciótervet készíteni, amiben körvonalazza azokat a tervezett lépéseket, amellyel az érintett jogszabályokat, illetve joggyakorlatot a Bizottság döntésének megfelelöen átalakítja. Egy másik lehetőség, ha a kollektív panaszt kezdeményező - vagy bármely más eljárásra egyébként jogosultsággal rendelkezö - szervezet nyomon követi a döntés betartását, és amennyiben hiányosságot tapasztal, újból kezdeményezi az eljárást. 
nyújtó szervezet ${ }^{34}$ és a képviseletében eljáró és aláíró személy jogosult a panaszt tevő szervezet képviseletére; annak az államnak a megnevezését, amely ellen a panasz irányul; annak pontos megjelölését, hogy a panaszolt jogsértés az ESZK mely cikkelyét vagy cikkelyeit sérti konkrétan ${ }^{35}$; a panasz tárgyát érintő, az ügy érdemére vonatkozó érveket, az azokat alátámasztó dokumentumok megjelölésével. Ha az eljárást az arra jogosult nemzetközi szervezetek vagy a Kormányzati Bizottság listáján szereplő NGO-k valamelyike indítja, akkor a panaszt valamelyik hivatalos nyelven (angolul vagy franciául) kell beterjeszteni, a részes államokban müködő szervezetek általi indítványozás esetében pedig az adott állam hivatalos nyelvén (vagy hivatalos nyelveinek egyikén).

A Bizottság a beérkezett panaszt megvizsgálja, és amennyiben a formai követelményeknek megfelel, érdemi eljárásra bocsátja. Az eljárásra bocsátással írásbeli eljárás indul, amely a felek közötti írásbeli feljegyzések kölcsönös megküldésével - általában két fordulóban - valósul meg. A Bizottság úgy is dönthet, hogy nyilvános tárgyalást tart, erre azonban nagyon ritkán kerül sor. A nyilvános tárgyalásra nem a Bizottságnak otthont adó Agora épületben, hanem az Emberi Jogok Európai Bíróságának tárgyalótermében kerül sor.

Ezt követően a Bizottság érdemben határoz a panaszról, amelyet jelentés formájában küld meg az érintett feleknek, valamint a Miniszteri Bizottságnak. Ennek a publikálása a továbbítást követő négy hónapon belül történik meg. Az eljárás lezárásaként a Miniszteri Bizottság határozatot (resolution) fogad el. Amennyiben indokolt, ajánlást (recommendation) tehet arra vonatkozóan, hogy a szóban forgó államnak milyen megfelelő intézkedéseket szükséges tennie az ESZK szabályainak megfelelő helyzet megteremtése érdekében.

\footnotetext{
${ }^{34}$ Ennek feltétele a reprezentativitás. A Bizottság előtti eljárásban a panaszt előterjesztő szervezet - akár szakszervezet, akár egyéb INGO, illetve csak Finnország esetében nemzeti NGO (lásd Finnish Society of Social Rights v. Finland, Complaint No. 107/2014, Decision on admissibility and on the merits of 6 September 2016, §§ 28-30) - reprezentativitása autonóm fogalom, és sok esetben eltér az adott állam jogrendszerében használt szakszervezeti reprezentativitás fogalmától. A legfontosabb előfeltételek: az érintett szektorban dolgozó munkavállalók többségét képviselje (lásd Tehy ry and STTK ry v. Finland, Complaint No. 10/2000, Decision on admissibility of 12 February $2001, \S 6$ ); országos szinten is reprezentatívnak minősüljön és rendelkezzen kollektív szerződéskötési képességgel; az alapítás helye szerinti földrajzi területen, egy meghatározott szektorban dolgozó munkavállalók többségének gazdasági és/vagy szociális érdekeit képviselje; és az állami hatóságoktól legyen független. Megítélésem szerint ez a fogalommeghatározás meglehetősen bizonytalan, de még ezt is tovább fokozza a Bizottság esetjoga, amikor kimondja, hogy amennyiben a kollektív panasz által érintett ügy fajsúlya nagyon jelentős, abban az esetben el lehet tekinteni a fentiekben vázolt reprezentativitási előfeltételek teljesítésétől. (Lásd például Syndicat national des dermato-vénérologues v. France, Complaint No. 28/2004, Decision on admissibility of 13 June 2005, § 5; Syndicat des hauts fonctionnaires v. France, Complaint No. 29/2005, Decision on admissibility of 14 June 2005, § 3.) A probléma gyökere a panasz „kollektív" jellegében rejlik. Megítélésem szerint a beadási jogosultságot (reprezentativitást) mint előfeltételt nem a - sokszor formális - létszámbeli feltételhez (kollektív munkajogi reprezentativitás), hanem a bepanaszolt kérdés szubsztanciális valódiságához, megalapozottságához és bizonyítottságához kellene kötni.

${ }^{35}$ Sok esetben előfordul, hogy a panaszt előterjesztő szervezet egyidejüleg az ESZK számos cikkét felhívja, de a panasz nem tartalmaz elegendő érvet és tényt a megjelölt cikkek megsértésére vonatkozóan. Ilyenkor az alaptalanul felhívott cikkeket a Bizottság figyelmen kívül hagyja. Itt nem arról van szó, hogy ne állna fenn esetleg jogsértés, hanem arról, hogy az nincs tényekkel, adatokkal stb. alátámasztva. A Bizottság pedig csak a benyújtott panasz alapján járhat el.
} 
A kollektív panaszeljárás értékeléseként előrebocsátható, hogy 1998-as bevezetése után fokozatosan fejlődve elősegítette az ESZK-ban foglalt jogok mint kiemelkedő emberi (szociális) jogi vívmányok érvényesülését. Ennek során elsősorban a nemzetközi szinten tevékenykedő szociális partnerek (kizárólagosan nevesített munkáltatói és munkavállalói érdekképviseleti szervek), valamint néhány nemzeti érdekképviselet szerepe és jogérvényesítési képessége erősödött meg. Külön kiemelkedő a kollektív panaszeljárás kontradiktórius jellege, amely a Bizottság döntéseinek megalapozottságát erősíti. ${ }^{36} \mathrm{E}$ tekintetben az ET létrejöttének hajnalán körvonalazódó, de később elvetett Európai Szociális Bíróság halvány müködési sziluettjét vetíti rá a tárgyalt ügyekre.

Ugyanakkor a kollektív panaszeljárás legsúlyosabb problémája, hogy formálisan nem bírósági ítélettel ér véget, ami azt jelenti, hogy a döntés közvetlenül nem kényszeríthető ki, illetve a be nem tartásának nincs közvetlen szankciója. Amíg ez a helyzet fennáll, addig a meghozott döntés maradéktalan kikényszerítése nem fog bekövetkezni. A marasztalt államok alapvetően az önkéntes jogkövetés, pontosabban „döntéskövetés” alapján hajtják azokat végre, már ha végrehajtják. Abban az esetben, ha az érintett állam nem tartja be a döntésben foglaltakat, akkor a Miniszteri Bizottság által kilátásba helyezett marasztalás sem jelent kikényszerítő erőt.

A kialakult helyzet megoldására - a szokásos kis lépéses reformoktól eltérően véleményem szerint két alternatíva körvonalazódik. Az egyik, hogy az eredeti elképzelésnek megfelelően létre kellene hozni a Szociális Jogok Európai Bíróságát. ${ }^{37}$ A másik, hogy a kollektív panaszeljárást egy alternatív vitarendezési formává lehetne átalakítani a Bizottság jelenlegi hatáskörének (országjelentések értékelése és kollektív panaszeljárás) és szervezetének (független választott testület) fenntartása mellett. Így a testület Szociális Jogok Európai Kollektív Döntőbizottságaként járna el. Az eljárás kétféleképpen lenne megvalósítható. Az egyik lehetőség a felek kölcsönös megállapodásán alapuló vitarendezési eljárás (például mediáció, közvetítés), a másik a felek kölcsönös és előzetes alávetésén alapuló, adjudikációs jellegű eljárás (arbitráció). Ez utóbbi eljárás feltétele, hogy azt megelőzően a felek kölcsönösen alávetési nyilatkozatot tegyenek, amelyben a kollektív döntőbíróság (maga a Bizottság) által hozott döntést magukra nézve kötelezőnek ismerik el, és az eljárás végén

\footnotetext{
${ }^{36}$ A panaszeljárás keretében a Bizottság „csak” az államok jelentéseit vizsgálja, és néhány kivételes esetet leszámítva a „hozott anyag” alapján ítéli meg az adott ország jogkövető magatartását és jogfejlődését. Ezzel szemben a kollektív panaszeljárásban a kezdetektől fogva biztosított és legalább két körben lehetséges a felek számára, hogy reagáljanak az őket ért vádakra.

${ }^{37}$ Ez a részes államok támogatása esetén két módon valósulhatna meg. Az egyik megoldás, ha az EJEB hatáskörét kiterjesztenék az ESZK cikkelyeire is. Ebben az esetben megszủnne a kollektív panasz (kvázi kereset) kollektív jellege, és magánszemélyek is nyújthatnának be keresetet a bírósághoz. Ebben az esetben a Bizottság hatásköre leszűkülne az országjelentések vizsgálatára (monitoring eljárás). A másik lehetőség, ha a Bizottságot, hatáskörének és jogállásának átalakításával, létszámának esetleges bővítése mellett sui generis bírósági rangra emelnék (Szociális Jogok Európai Bírósága), a kollektív panaszrendszer eljárását is átalakítva, de megtartva annak kollektív jellegét. Az újonnan létrejövő bíróságnak lenne egy kötelező normakontroll funkciója (az ESZK és a nemzeti joggyakorlat megfelelőségének vizsgálata), ami megegyezik a jelenlegi állami jelentéseken alapuló monitoring eljárással. Ezt egészítené ki a jelenlegi kollektív panaszeljárást felváltó kollektív adjudikációs eljárás. Ennek értelmében a jelenleg felhatalmazott szervezetek nyújthatnának be kollektív keresetet kvázi az actio popularis mintájára.
} 
azt önkéntesen végrehajtják. A javaslat hátterében az az elképzelés áll, amely a jövőre nézve a formalizált, nyertes-vesztes felállású bírósági eljárások visszaszorulását vetíti elöre. Természetesen a konfliktusok, jogsértések a jövőben sem fognak megszűnni, de ezek rendezésére a kölcsönös érdekeken alapuló megoldás lehetöségét nyújtó alternatív vitamegoldások (alternative dispute resolutions), valamint a viták arányos rendezése (proportionate dispute resolutions) a nemzetközi emberi (szociális) jogi viták vonatkozásában is meghatározó szerephez juthatnak. ${ }^{38}$

\subsection{Az ESZK el nem fogadott cikkelyeire vonatkozó eljárás}

Ezt az eljárást a Kartákban foglalt emberi (szociális) jogok minél szélesebb körü érvényesülése és az azzal kapcsolatban a részes államok között fennálló, az à la carte jellegủ ratifikációból eredő eltérések kiküszöbölésére vagy legalább csökkentésére hozták létre. Lényege, hogy a részes államok által el nem fogadott ESZK cikkelyek, bekezdések ratifikációját ösztönözze. Erre minden részes állam esetében általában ötévente kerül sor. Az eljárásnak két formája létezik: a szakértői szintü közös egyeztetés (személyes jelenléten alapuló eljárás) és az írásbeli eljárás. ${ }^{39}$

A szakértői egyeztetés keretében az ET részéről a Bizottság két tagja és az ESZK Tikárságáról általában 1-2 fő előzetes egyeztetést követően látogat el az eljárásban érintett államba. Az egyeztetés egy előre meghatározott tematika szerint, az adott ország által nem ratifikált cikkelyek vizsgálata mentén folyik. A fogadó állam összeállít egy nemzeti szakértői csoportot, amelynek tagjai a napirenden szereplő cikkelyekért felelős közigazgatási szerveknél (rendszerint vezető beosztásban) dolgoznak, és egy-egy téma kiemelt hazai szakértői. Az egyeztetésen először az ESZK szakértői prezentálják az adott állam által nem ratifikált cikkelyekkel szembeni elvárásokat. Ezek forrása az ESZK Kommentár (Digest), amely az ESZK cikkelyek részletes magyarázatából, a Bizottság (monitoring) eljárásokban, illetve kollektív panaszeljárásokban kialakult esetjogából, valamint az ad hoc jelleggel kiadott értelmező nyilatkozatokból (statement of interpretation) ${ }^{40}$ áll. Ezt követően a fogadó állam szakértői előadják saját álláspontjukat az érintett cikkelyekről. Ezt a részt vevő felek közötti rövid egyeztetés követi. Az egyeztetés végén a Bizottság szakértői egy rövid összegző értékelést tartanak minden vizsgált cikkelyről, elsősorban arra vonatkozóan, hogy az adott ország reálisan melyik cikkely ratifikálásához áll a legközelebb. Minden egyeztetés napirendjén szerepel a kollektív panaszeljárás legfontosabb is-

${ }^{38}$ McGREGoR, Lorna: Alternative Dispute Resolution and Human Rights: Developing a Rights-Based Approach through the ECHR. European Journal of International Law, 2015/3, 607-634.

${ }^{39}$ A Szociális Karta dióhéjban: i. $m$.

${ }^{40} \mathrm{Az}$ értelmező nyilatkozatot a Bizottság saját kezdeményezésére és saját szakértelme alapján fogalmazza meg. Annak érdekében, hogy minél nagyobb legyen a részes államok jogkövetési hajlandósága, felmerült, hogy az értelmező nyilatkozat megszövegezése során az államok képviselői egy transzparens eljárás keretében véleményezhetnék a szöveget és hozzáfúzhetnék saját meglátásaikat. (Ez részben jelenleg is megvan, de a lehetőséget lehetne bővíteni és az együttműködést mélyíteni.) Sőt, az is megfogalmazódott, hogy a Miniszteri Bizottság egyes értelmező nyilatkozatokat konkrétan bizonyos - a felmerült problémával kapcsolatban az ESZK rendelkezéseit be nem tartó - ország(ok)nak címezze. 
mérveinek bemutatása annak érdekében, hogy minél több állam fogadja el az ESZK leginkább kontradiktórius ellenőrzési mechanizmusát, amely a Bizottság szerint a szociális jogok hatékonyabb érvényesülését szolgálja.

Az írásbeli eljárásra általában akkor kerül sor, ha az adott ország csak néhány cikkelyt nem ratifikált, de kifejezi szándékát a bővítésre, ezért nem kell személyes egyeztetésen keresztül elősegíteni a ratifikációs lendületet. Emellett az is indokolhatja az írásbeli eljárást, ha a szakértői látogatást valamilyen objektív ok miatt nem lehet megszervezni. Erre a legjobb példa a COVID-19 pandémia miatt kialakult utazási korlátozás volt. Ebben a helyzetben az érintett államok írásban tettek jelentést arról, hogy milyen elörelépések várhatók az elkövetkezendő öt évben. A Bizottság megvizsgálja a jelentést, és írásban visszajelez.

\section{3. Összegzés}

Az ESZK az ET tagállamai számára 60 éve jogalkotási, jogalkalmazási és lelkiismereti iránytűként szolgál annak érdekében, hogy állampolgáraik számára biztosítottak legyenek az alapvető emberi (szociális) jogok. Optimális helyzetben a minél nagyobb számú ratifikáció hatására és a két ellenőrzési mechanizmus, a jelentéstétel és a kollektív panaszeljárás eredményeként a részes államok megváltoztatják jogszabályaikat és/vagy gyakorlatukat annak érdekében, hogy az ESZK-val összhangban lévő jogi helyzetet teremtsenek. Polgáraiknak ez nem jelenthet mást, mint az élet- és munkakörülményeik javulását. Ugyanakkor jelentős eltérések mutatkoznak a részes államok között, mind mennyiségi (eltérő számú ratifikáció), mind társadalmi, tudati, mind gazdasági, mind végrehajtási szinten. A részes államok közötti különbségek egyértelmủen visszatükröződnek a Bizottság éves jelentéseiben.

Az elmúlt 60 évről tisztelettel megemlékező, de az alkalmazási problémákat is felvillantó írásból remélhetőleg kiderült, hogy a Karták müködési mechanizmusa és a bennük foglalt emberi (szociális) jogok védelme számos ponton reformra szorul. Ezért a felvetett problémákra reflektáló dogmatikai kérdések és de lege ferenda javaslatok is megfogalmazásra kerültek. Ugyanakkor szem elött kell tartani, hogy a reform minden kis lépése, amely az ET és a tagállamok szintjén elsősorban a Bizottság ösztönzésére megvalósul, hatalmas ugrás az európai közösségnek. Ezért a feladatunk soha nem érhet véget. 